\title{
Intervention Model of Children Growth and Development to Improve Stimulation Skills of Parents with Early Child
}

\author{
Nissa Tarnoto, Fatwa Tentama, Dessy Pranungsari \\ Psychology Departement, Ahmad Dahlan University, Yogyakarta, Indonesia.
}

Nissa.tarnoto@psy.uad.ac.id, fatwa.tentama@psy.uad.ac.id,dessyuad@gmail.com

\begin{abstract}
The purpose of this study is to determine the effect of intervention model in children growth and development to improve stimulation skills of parents with young children. Design of experiments uses a quasi-experimental of one-group pretest-posttest design. Methods of data collection use a scale of stimulation skills. Subjects in this study are the parents who have early children in child care, the children were born normal and subjects are parents whose children attend child care of Ar Royyan Yogyakarta. The data analyzed using the Wilcoxon by SPSS 17.0 for Windows. The results showed the $t=-4.341$ and $p=0.001)(2$-tailed) $(p<0: 01)$, this means very significant. Thus, there are significant differences stimulation skill level of parents of early children between pretest is given and after the intervention (posttest). The average skill level of stimulation of parents of early children intervention is higher after given the intervention.
\end{abstract}

Keywords: stimulation skills, intervention model, chilhood.

\section{INTRODUCTION}

Improving Indonesian human resources is not an easy thing for it involves many factors and requires much time and long processes. It may begin from the lowest level i.e from the family. As a matter of fact, most children in developing countries are not protected from risk factors in their developments such as health, malnutrition and the low stimulation at home (Baker and Henningham, 2010). Poverty normally goes hand in hand with low knowledge of child care, low home stimulation, and high depression of parenting (Baker \& Hennington, 2010)

Children growth of good human resources begins from child birth or early stage through good stimulation at different aspects of development such as motoric, moral, social, as well as language and emotional aspects. Giving stimulation on those aspects to the children at early stage from their parents will affect the children's language and memory (Farah et.al, 2008). Early stimulation can improve their readiness to attend school and help them to maximize the potentials for their lives (Children \& Youth Unit, 2009). This fact is supported by the research done by Yousafzai, Rashed, Rizui, Amstrong, and Bhutta (2014), which says that the children given early stimulation achieve high development score at cognitive, motoric, social as well as language and emotion aspects. Another research shows that a child with early psychosocial stimulation through social interaction such as mother and her child to be involved in playing games as well as making toys together show an improved score in mental and psychomotoric developments (Nahar et.al, 2012). Various research results conclude that early child development affects his futher development and his work productivity at his adulthood phase so that maximum stimulation should be given at early stage. (Aisyah, 2008). Early childhood is very important for the child development so that it is called golden age because the child's intelligent development grows $40 \%$ up to the age of four years. Early stimulation is necessary to stimulate all children's development aspects. At the critical period the child needs stimulation to optimize the development his potentials (Soetjiningsih, 2003)

Nowadays many parents misinterpret the meaning of stimulation. They define stimulation giving many materials to their children without considering their developmental aspects such as language, emotion, and social feelings. The parents tend to oblige the children to learn how to write and to read at early stage by asking them to attend reading and writing courses hoping that they will acquire good academic achievement. Doing so, in fact they have compeled the children to attend the courses so that they feel they have no chance to play. The parents do not realize the advantages of playing. The advantages of palying are satisfying their desire and needs in accordance with their cognitive, motoric, social, as well as emotion, language, creativity and attitude developments. Through playing, children can get opportunities to decide which activities they like. Furthermore, they can also make some experiments with different materials and instruments. They can also develop their imagination; solve some problems, converse freely with their friends, work together in 
groups, and experience pleasing moments (Moslichatoen, 1999).

According to Santrock (2002) the main characteristic of children at early age is love playing. All playing activities for children at their early stage are the activities to develop their brain capacity. In other words, playing with children at their early stage with various safe and pleasing games full of laughter means we are developing their dendrites or nerve cells, which develop trillions of synapses. The parents also give stimulation to the children through Idonesian traditional games. In addition, introducing the endangered traditional games to children, parents can make use of the games for children advantages. According to Hidayat (2013) the games can train the children's rough and soft motoric skills, improve their cognitive, social, and emotional developments of their moral and spiritual aspects.

Most parents think that stimulating children should use various expensive toys. Parents with low income cannot afford to buy such expensive toys. In fact stimulating children can be done without such expensive toys, the most important thing is that the toys are safe for children and are advantageous for their development. Stimulating children can be done using the toys made by parents and children together with the available materials such as unused bottles, newspaper leaves, cartons, wood, leaves, etc. Some experts say that stimulating children can be done using simple and safe toys around the children (Health Ministry, 2006). Stimulating children is an activity to rouse the 0-6 year aged children's basic skills to develop optimally. Those basic skills to develop include rough motoric skill, soft motoric skill, talking skill, and language skill as well as social and selfsupporting skills (Health ministry, 2006)

Another phenomenon is the progress of science and technogy. Many parents introduce educative electronic as well as uneducative games in the gadget to their children very early without realizing considering on the negative impact. As a matter of fact, the negative impact of introducing gadget to the children early is greater than its positive impact. This fact is supported by some reasearch results done by Rtzhaupt, Higgins, and Alfred (2011) which say that there is no significant achievement in mathematics among children using educational modern games. Kang, Kim and Kim (2013) also say that spending much time for playing games, internet and using mobile phones can make them addicted to them. Furthermore, Bevelier et.al (2011) asserts that modern game can cause negative impacts such as reducing the children's concentration range, changing the children's social behavior towards the environment, reducing their emphaty, revealing anti-social behaviors, showing disturbing behaviors, and becoming unsociable.

Based on the issue, the researcher finds it necessary o find a model of growing and developing intervention to improve parents' skill in stimulating their children so that it can be implemented to stimulate them maximally. The intervention to stimulate the children is through making use of things around the subjects of the research such as stimulation using educational game toys (EGT) from recycled toys so that the subjects of the research can make use of anything around them to stimulate the children. This is done to consider the economic condition of the people in Indonesia, who are from middle and low economic societies.

The hypotheses of the research are firstlywheather the model of growing and developing children intervention is effective to improve the parents' stimulation skill for children at early stage. Secondly, wheather there is a difference of parents' stimulation skill between before and after the training of model of growing and developing stimulation at experimental group. The rate of the parents' stimulation skill after the training is higher than before the training.

\section{METHODS}

\section{Participant}

The subjects of the research are:

1. The parents having early age children.

2. The parents taking care of their own children.

3. The children with normal birth (not premature one).

4. The parents whose children attend Arroyan Preschool/kindergarten in Yogyakarta.

\section{Research Design}

The design of experiment used in this research is quasi experimental One-Group Prestest-Postest Design. The pre-test is done before the intervention training is given and the posttest is given a week after the last session of the intervention training. In this research the researcher decides not to use the control group due to the lack of the number of subjects in the field besides other reasons such the limited fund, time, availability of the researcher.

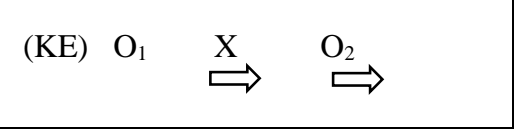

Legend: 01 : Measurement before the treatment (pretest)

O2: Measurement after the treatment (post-test)

$\mathrm{X}$ :The treatment i.e. the training of child-growing and developing intervention model

Figure 1. The Chart of Experimental Design 


\section{Measures}

The stimulation skill is exposed through stimulation skill scale. The scale uses the existing scale, which was previously tested its validity and reliability and it was organized by the researcher referring to the guidance of implementation of early child stimulation, detection, and intervention for growth and development at the basic health service (2006). The characteristic of good stimulation are as follow:

1. The stimulation is carried out with the consideration of feeling love and affection.

2. Good attitude and behavior should be maintained for children who would immitate the behavior and attitude of people around them.

3. The stimulation should be in accordance with the children's age.

4. The stimulation should be done by asking the children to play games and sing songs voluntarily without imposing obligation and make sure there is no punishment.

5. The stimulation should be done step by step and continuously in accordance with the children's age and their four basic skill aspects.

6. The stimulation should make use of simple and safe toys around the children.

7. The stimulation should equally give opportunity to both boys and girls.

8. The children should be given rewards for their achievements.

The type of validity used in this research is the content validity in which test items are written in line with measurement domain limits that previously determined and the capability to reveal the objects. In examining content of the test professional judgement is used i.e. test items are consulted to experts so that the item scale suit to the blue print. After a try out, the items to obtain the data are selected (Azwar, 2004).

The results of validity and reliability tests from the previous measurement instrument amount 32 stimulation skill scale items show the reliability coefficient of 0.933 with difference index range from 0.319 to 0.864 . All the 32 items are valid and reliable and they are used in the research.

\section{Procedure}

The stages of the research are:

a. The researcher assisted by the research assistants distribute informed consent to the subjects of the research in relation to their availability and they are informed about the implementation of training so that they can spare their time to follow the training of intervention for growing and developing children. b. Before training of intervention for growing and developing children, the researcher aks the subjects to fill in the scale of stimulation skill as a pre-test.

c. The researcher coordinates and simulates the prepared modul of intervention for child's growing and developing with the help of the research assistants to make sure the program is ready to carry out.

d. The impelementation of the training of child growing and developing intervention.

The implementation of intervention model for child growing and developing consists of 5 sessions.

Table 1. Intervention Session

\begin{tabular}{ll}
\hline Session & Material \\
\hline Session 1 & Stages of child development \\
\hline Session 2 & The impotance of child stimulation \\
\hline Session 3 & Ways of child stimulation \\
\hline Session 4 & $\begin{array}{l}\text { The practice of making educative toys from } \\
\text { used materials. }\end{array}$ \\
\hline Session 5 & $\begin{array}{l}\text { Role Play, giving a model of how to stimulate } \\
\text { children with the toys made of used materials } \\
\text { produced in the training and directly practiced } \\
\text { to the children. }\end{array}$ \\
\hline
\end{tabular}

e. After the training of intervention for child growing and developing, the researcher asks the subjects of the research to complete the stimulation skill scale (Post-test).

\section{Data Analysis}

In analyzing the data the Wilcoxon non-parametric statistical test is used to measure the stimulation skill level difference between the results of pre-test and posttest of the experimental group. The analysis is done by means of SPSS 17.0 for windows.

\section{RESULTS}

The mean score of scale of stimulation skill of the pre-test and post-test are the followings:

Table2. Mean of Stimulation skill scale score

\begin{tabular}{ll}
\hline Measurement & MeanScore \\
\hline Pretest & 124.88 \\
Postest & 128.38 \\
& \\
\hline
\end{tabular}

From table 2 the difference of mean scores of the early child parents' stimulation skill can be seen. The early child parents' pre-test stimulation skill score improves in the post-test. It means there is an improvement in the early child parents' stimulation skill before and after the intervention taining of child growing and developing. The result is supported by the Wilcoxon test to know the significant difference between the pretest and the post-test. The result can be seen in the following: 


\section{Wilcoxon Test}

The result of Wilcoxon test is shown in the following table 3 .

\begin{tabular}{lllll}
\multicolumn{4}{c}{ Table 3. The Summary of Wilcoxon Test Result } \\
\hline Source & $\begin{array}{l}\text { Mean } \\
\text { Difference }\end{array}$ & $\mathbf{Z}$ & $\mathbf{P}$ & \\
& & & & \\
\hline $\begin{array}{l}\text { Pretest- } \\
\text { postest }\end{array}$ & 3.5 & -3.082 & 0.002 & (2- \\
& & & tailed) / & \\
& & 0.001 & (1- \\
& & tailed) & \\
\hline
\end{tabular}

Based on the above mentioned table the result of Wilcoxon test to show the difference level of early child parents' stimulation skill indicates the pre-test and posttest results of $\mathrm{Z}=-3.082$ and $\mathrm{p}=0.001$ (1-tailed) so that $\mathrm{p}<0.01$, which is very significant. It means there is a very significant difference of the early child parents' stimulation skill level between before training (pre-test) and after the training of intervention (post-test). The average of level of early child parents' stimulation skill after the training of child growing and developing intervention is higher than before the training.

The hypothesis of this research notes that there is a difference between the levels of the parents's child stimulation skill before and after the training of child growing and developing method to the experimental group. The average of child stimulation skill score after the training is higher than before the training of child growing and developing intervention is accepted. It means the training of child growing and developing intervention is effective to improve the early child parents' stimulation skill.

\section{DISCUSSION}

Based on the research result, it is known that the child growth and development intervention affects significantly to the early child parents' stimulation skill. This is because the parents has no prior knowledge and skill of how to stimulate early children. Most of the trainees think that the stimulation can only be done by the schools with complete facilities. They tend to focus on the cognitive aspects of the child development without paying attention to other developmental aspects. Hurlock (2006) says that the child developmental aspects covers some aspects such as motoric, social, spatial, emotional, and moral developmental aspects as well as language developmental aspect. Because of this, the researcher introduces some knowledge of developmental aspects for stimulation to early children not only the cognitive developmental aspect. Those aspects will reciprocally influence the children's future development. The finding is supported by some other rsearches, which show that intelligence quotion is not the only thing that determines the children's success at their adult age (Wulan, 2010)
In this training the trainer also introduces the importance of early child stimulation so that parents will be aware of giving stimulation to their children. Some experts in neurology also support the idea, that the chidren's brain is not a static organ but it is dynamic. It grows and develops to form nerve cell connection. The development of the cells is influenced by the stimuli from the environment so that the more the children are stimulated the more brain cells develop. It means the children will be more intelligent (Sidiarto, 2010).

The parents are also introduced to giving stimulation correctly to the children with the basic principles of correct stimulation based on the 2006 instruction of Indonesian Health Department so that they do not carelessly give stimulation to their children. One of the good and correct stimulation principles is that the stimulation should be given pleasantly without pressure. It can be done through games and singing songs so that parents in the training are asked to practice role playing with the children. According to Manorom and Pallock (2006), role play method is a teaching method which is useful to develop skills as well as academic potentials through environmental stimulation processes so that the parents are expected to practice giving the stimulation to the children directly and the children feel no burden. Moeslichatoen (1999) also says that the advantage of playing games for children is that it fulfills their demands and needs for their motoric, cognitive, creativity, language emotion as well as their social needs and attitudes of life. Through playing activities children can get a chance to choose the activities they like, to experiment with different materials and instrument, to imagine and to solve problems, to converse freely, to work together in a group, and to get joyful experience.

Moreover, the stimulation is done step by step in accordance to the children's development so that some materials related to the child development is given in the training hoping that the parents will not force their children to acquire certain achievement but they have to adjust to the children's development.

Another stimulation principle is that the stimulation should be done with simple and safe toys available in the children's environment (Health Deparment, 2006). For this reason the parents in this training are asked to stimulate the children by means of making toys from used materials such as used bottles, cartons, paper, wood / stick together with the children. According to the observation in the field the parents are eager and enthusiastic to create the toys together with their children, admitting that they rarely do this at home and they are happy to start creating such toys at home. Thus, children's and parents' creativity are improved. It turns that from the same materials they can create different products such as toys of cars, bucket, fruits, animals, and person. Other than the creativity development is improved, the children's motoric skill is stimulated where the children help the parents to cut, fold, and wring etc. The children can also help their friends and their parents then in turn they play with their products they have made. 
The parents in this training indirectly stimulate the children's developmental aspects of social and emotional aspects so that in a game the parents have stimulated some of their developmental aspects together. This fact is supported by Aisyah (2008) who says that the stimulation given to the children should be holistic, which means in a game or in an instruction given to the early children should stimulate some aspects of their development at once.

Based on the research result it can be concluded that the model of child growth and development intervention significantly affects the improvement of the early child parents' stimulation skill so that it is necessary to train early child parents because not all parents master the knowledge and skill of how to stimulate their children well and correctly. This will support the early child development maximally.

\section{REFERENCES}

Aisyah, S. (2008). Perkembangan dan konsep dasar pengembangan anak usiadini. Jakarta: Universitas Terbuka.

Alwi, H. (2005). Kamus besar bahasa indonesia. Jakarta: Balai Pustaka.

Azwar, S. (2004). Dasar-dasar psikometri. Edisi 1. Yogyakarta: Pustaka Pelajar.

Azwar, S. (2005). Penyusunan skala psikologi. Edisi 1. Yogyakarta: Pustaka Pelajar.

Azwar, S. (2006). Reliabilitas dan validitas. Edisi 3. Yogyakarta: Pustaka Pelajar.

Baker, H \& Henningham. (2010). Early childhood stimulation interventions in developing countris: A comprehensive literature review. Lopez Boo and Inter-American Developmant Bank (Social Protection and Health Division). Amerika.

Bavelier, D.,Green, C.S,. Han, D.H,. Renshaw, F.F,. Merzenich, M.M. \& Gentile, D.A,. (2011). Brains on video games. Journal Nature Reviews Neuroscience, 12, 763-768.

Children \& Youth Unit Development (The World Bank). (2009). Suplementing nutrion in the early years: The role of early childhood stimulation to maximize nutrional inputs. Notes Children \& Youth Development, 3 (1) ,1-4.

Dalton, J. (2000). Community psychology. USA: Wordworth

Departemen Kesehatan, Direktorat Jenderal Pembinaan Kesehatan Masyarakat. (2006). Pedoman pelaksanaan stimulasi, deteksi dan intervensi dini tumbuh kembang anak ditingkat pelayanan kesehatan dasar. Jakarta

Effendi, I. (2008). Gangguan komunikasi. www.dokteranakku.com/Buku\%20gangguan\%20bi cara\%20dan\%20bahasa.pdf. Diunduh 5 Juli 2016.

Farah, M.J., Betancourt, L,. Savage, J.H., Shera, D.M., Giannetta, J.M., Brodsky, N.L., Malmud, E.K., \& Hurt, H. (2008). Enviromental stimulation, parental nurturance and cognitif development in humans. Journal Developmental Science. 11 (5), 793-801.

Hidayat, D. (2013). Permainan tradisional dan kearifan lokal kampung dukuh Garut Selatan Jawa Barat. Jurnal Academica. 5. (2).
Hurlock, E.B. (2006). Perkembangan anak. Jakarta: Gramedia Pustaka.

Khang, H,.Kim, J,. \& Kim, Y,. (2013). Self-traits and motivations as antecedent of digital and addiction: The internet, mobile phones, and video games. Journal Computers in Human Behavior. 29 (6), 2416-2424.

Moeslichatoen, R. (1999). Metode pengajaran di taman kanakkanak. Pusat Perbukuan Departemen Pendidikan dan Kebudayaan. Rineka Cipta: Jakarta.

Nahar, B., Hossain, M.I., Hamadani, J.D., Ahmed, T., Huda, S.N., Gregor, M.C., \& Person, L.A. (2012). Effects of a community-based approach of food and psychosocial stimulation on growth and development of severely malnourished children in Bangladesh: A randomised trial. European Journal of Clinical Nutrition, 66, 701-709.

Manorom, K., \& Pollock, Z., 2006. Role play as a teaching method: A practical guide. Journal of Role Playing as a Teaching Method, 84, 5-1.

Poerwadarminta. (2001). Kamus umum bahasa indonesia. Jakarta: Balai Pustaka

Ritzhaupt, A., Higgins, H and Allred, B. (2011). Effects of modern educational game play on attitudes toward mathematics, mathematic self-efficacy, and mathematics achievement. Journal of Interactive Learning Research. 22 (2). 277-297.

Santrock, J. W. (2004). Life Span Devellopment. New York: McGraw-Hill Education

Sidiarto, L.J. (2010). Perkembangan otak dan kesulitasn belajar pada anak. Jakarta : UI Press.

Soetjiningsih. (1995). Tumbuh kembang. Jakarta: EGC.

Yousafzai, A.K., Rashed, M.A., Rizvi, A., Amstrong, R. \& Bhutta, Z.A. (2014). Effect of integrated responsive stimulation and nutrition intervention in the lady health worker programme in Pakistan on child development, growth, and health: Outcomes: A cluster-randomised factorial effectiveness trial. www.thelancet.com, 384, 1282-1293.

Wulan, R. (2011). Mengasah kecerdasan anak. Yogyakarta: Pustaka Pelajar. 